\title{
Relationship between Permissive Parenting Style and Examination Cheating Tendencies among Kenya Secondary School Students
}

\author{
Pascal Ochieng Opiyo \\ Agoro Oyombe Secondary School, \\ Ngiya, Kenya \\ Dr Peter J.O. Aloka \\ Psychology \& Educational Foundations, \\ Jaramogi Oginga Odinga University of Science \& Technology \\ Dr Pamela A. Raburu \\ Psychology \& Educational Foundations, \\ Jaramogi Oginga Odinga University of Science \& Technology

\section{Dr John Agwaya Aomo} \\ Kitutu Central Sub-County Education Office, \\ Kisii, Kenya
}

Doi: 10.2478/mjss-2018-0064

\section{Abstract}

The study investigated the relationship between permissive parenting styles and examination cheating tendencies among secondary school students in Siaya Sub County, Kenya. Diana Baumrind's parenting styles theory and Ajzen's theory of Planned Behaviour provided a theoretical framework for the study while adopting a Correlational study design within a mixed methods approach. The target population was 1,908 form three students, 35 Teacher Counselors and 35 Deputy Principals. A sample size of 190 Form Three students, which was $10 \%$ of the population of students, was used after stratified random sampling. In addition, 8 Teacher Counselors and 8 Deputy Principals purposively sampled formed part of the participants. Parenting style and Involvement in Examination Cheating Tendency Questionnaires were used to collect quantitative data from form three students while interview schedule was used to collect qualitative data from the Teacher Counselors and Deputy Principals. Validity was ascertained by expert judgment of two university lecturers while reliability of the instrument was ensured using Cronchbar reliability test, where an index of 0.77413 was obtained. Quantitative data was analyzed using descriptive statistics as well as inferential statistics such as Pearson Correlation, aided by SPSS version 22, while qualitative data was analyzed through thematic framework. The findings revealed that permissive parenting has a strong positive influence on examination cheating tendencies with $r=0.641$ $p<0.05$. The study recommended that Kenyan Teachers' Service Commission should train more teacher counselors in schools to cope with the large number of students who have varied parental backgrounds.

Keywords: Relationship; Permissive Parenting Style; Examination Cheating Tendencies; Kenya; Secondary School; Students

\section{Introduction}

Cheating among students in academic settings such as schools and universities has existed for many years and can be traced back to Ancient China when the Chinese administered examinations 
for jobs in the civil service (Schiphorst, 2013). Academic cheating can be defined as being found in possession or copying from materials brought into an exam that are not specifically permitted or allowing a student to copy from one's exam paper through oral, symbolic, written and electronic or any other means (Desalegn and Berhan, 2014). Mukras (2013) however, viewed academic cheating as a practice of deceit by student examinee for personal gain through an attempt to illegally acquire a grade or improve his grade by dishonest, unfair and unethical means. Separate studies, by Antonio and Maria (2014) and Henning, Ram, Malpas and Shulrus (2013) have shown that cheating is one of the main factors which leads to faulty assessment and hence renders a false message on evaluation of students. The act of examination cheating therefore has the ferocity to dilute, erode and corrupt the meaning and purpose of assessment within the schools. Mutwiri (2010) highlighted that Public examinations ought to be reliable, relevant, and efficient given the role such examinations play as standardized basis for gauging and evaluating the educational system and for making important decisions about a learner.

Simkin and McLeod (2010) indicated that cheating is not a random, accidental, or impulsive act, but rather a premeditated, intentional and a deliberate one that requires forethought and planning. According to Mukras (2013), the phenomenon of cheating in examinations is neither new nor confined to some specific regions in sub-Saharan Africa, but is a universal education challenge.

A study by Gentina, Tang and $\mathrm{Gu}$ (2015) in France and China showed that parental attachment, academic commitment, and moral values curb academic cheating and that counterintuitively, peer involvement contributes to cheating. Another similar study provided distinct global perspective to examination cheating with pronounced differences between developed countries like the United States of America (U.S.A) and developing countries. The study was conducted by Marek, Helen, Klein, and Nancy (2013) and revealed key differences in cheating behaviours between collectivist cultures where students reported higher levels of cheating behaviours than individualistic cultures like USA where cheating reports were lower. In another study, Watson and James (2010), attempted to establish cheating behaviors of students in on-line classes and face to face classes among undergraduate and graduate students and showed a significant likelihood for students to cheat in on- line platforms.

A different study by Desalegn et all (2014), in Ethiopia showed a broad prevalence of cheating among medical students A study by Chinamasa, Mavuru, Maphosa, Tarambawamwe (2011), in Zimbabwe established that students Cheat by using crib notes, which are smuggled into the examination room on body parts, clothing and materials used in the examination. Students also use Silent cell phones to carry answer notes in the Inbox and Outbox modes. The findings were similar to those by Ali (2011) and Leopard (2017) that further showed that gestures and coordinated body language like facial expression and hand -fingure gestures are commonly used in examination cheating by students. The findings were corroborated in a study by Ogunlade (2013) in Nigeria that established that mobile telephony has helped escalate cheating among students as learners resort to Bluetooth, swap text messages and programmable calculators to contravene most of the examinations regulations. A study by Ravasco (2012) appeared to equally show that technology is responsible for the increase in examination cheating among students and that online examinations and e- learning have been greatly affected.

Christopher, Eden, and Melody (2014), in Ghana reported that peer cheating was a stronger predictor of academic cheating. The findings were consistent with that of a study by Hingovei, Perry, Rishi, Byron and Brandon (2016). In Kenya, the challenge has been how to strike a balance between holistic education and academic grade acquisition. An aggressive preference for paper qualification by a majority of the population coupled with lack of positive self concept, lack of effective study skills, inadequate preparation and laziness are some of the causes identified to influence examination malpractice in Kenya. In addition, summative evaluation of students both at KCPE and KCSE has equally been viewed as a silent predisposer to examination cheating. Kafwa, Mwaka, and Musamas (2014) viewed summative norm -referenced evaluation to carry a lot of weight in the life of Kenyan citizens and as a result, saw the system as being abused. The study queried if the systems as currently designed serves the interest of the population. Similarly, Mwaka , Kegode, Wambua (2010) in Kenya found out that an examination- oriented education system that presents a cut-throat chase for grades with little regard to acquisition of skills and concepts should 
be blamed for the increase in cheating cases in schools.

Ndege (2012) further showed that there has been an increase in the frequency of examination irregularities in Kenyan public examinations and that the phenomenon of cheating starts as a rampant behaviour within the classroom situation where the act is practiced, perfected and transferred for use in the external final examinations. Further, the study showed that candidates who cheated in the Kenya Certificate of Primary Examination (KCPE) can be traced to have cheated in the KCSE examination. The effects of cheating are enormous, findings of a study by Latova and Latov (2008), indicated that academic cheating correlates with unethical behaviour on the job and might be projected by extension to unethical behaviours in the society as Meng, Othman, Silva and Omar (2014) observed that recent years have seen a series of high profile scandals and corporate collapses as a result of unethical behaviours at the work place. The Inter University Council for East Africa (IUCEA), (2014) also found out that only $49 \%$ of graduates in Kenya are fit for the job market and that the nature of graduates within the region is contributing to the slow growth of the East African economy. This study seemed to concur with an earlier study by Mwamwenda (2013) whose findings clearly indicated that academic dishonesty is widely practiced by East African students. According to Benedette, Cornelious, Ndifon and Obima (2012), cheating is a pervasive problem in education and the extent to which students engage in the act has greatly increased.

The policy on evaluation and assessments are guided by the policy makers in the Ministry of Education in Kenya for different levels of schools and middle level tertiary institutions. Kenyan secondary schools have only one source of evaluating body; Kenya National Examination Council (KNEC) that is mandated through the ministry of education to set and administer summative evaluations in all government approved learning institutions, both public and private ( Ministry of Education, 2012). Literature available has shown notables behavioural challenges for children raised by permissive parenting. According to Baumrind (1991), Permissive parents are more responsive than they are demanding. They are non-traditional and lenient, do not require mature behavior, allow considerable self-regulation, and avoid confrontation. It is because of such parenting environment that a study by Lashgari ,Karami and Golzari (2014) carried out in Iran established that significant and positive correlation existed between permissive parenting style and anxious problems among students with learning disabilities. Another study carried out in Bristol UK by Russel, Kirsten and Angie (2011) also found out that children with permissive mothers watched more than four hours of TV per day. In a separate study conducted by Changalwa, Ndurumo, Barasa and Poipoi (2012) established that a significant relationship existed between permissive parenting style and alcohol abuse among college students. Several studies therefore have been done on the behavioural nature of children raised by permissive parenting with scarce information being available on the influence of permissive parenting on examination cheating tendencies among secondary school students.

\section{Research Methodology}

The present study employed Correlational Research design. According to Creswell (2013), Correlational research designs are used by investigators to describe and measure the degree of relationship between two or more variables or sets of scores. The design is further suitable when data is to be collected from a relatively large sample. The Sub County had 35 secondary schools with a total of 1,908 Form three students, 35 Deputy Principals and 35 teacher counselors. The study targeted form three students since they have three years experience of examinations in secondary schools, in addition, the ethical sensitivity of the study would make the form three students volunteer information better than the form four students. Deputy Principals and teacher counselors are administratively the first door of call in students discipline and were found to be useful custodians of students' behaviour records. One hundred and ninety (190) students which is Ten percent $(10 \%)$ of the entire students population was used in the study. In addition, eleven schools $(30 \%)$ were targeted. Oso and Onen (2011) recommend that a sample size of between $10 \%-30 \%$ should be considered adequate for a study. However, 8 Deputy Principals and Teacher Counsellors were interviewed. This number fell within the 6-8 persons recommended to be 
adequate for an interview by Mason, (2010). Purposive sampling was used to select the eight (8) deputy principals and eight (8) teacher counselors.

Quantitative data was collected using questionnaires. A parenting style questionnaire and examination cheating questionnaire was used. The researcher used face-to-face interviews to collect the qualitative data. The structured interview schedules with open-ended questions were used in this study. The interview participants were the deputy principals and teacher counselors.

Validity is establishing whether the instrument content is measuring what it is supposed to measure (Oso et al, 2011). This was evaluated in terms of face validity, content validity and/or construct validity. To determine the validity of the questionnaire, the opinion of two lecturers in the department of Psychology and Educational Foundations at Jaramogi Oginga Odinga University of Science and Technology was sought and adopted.The reliability of the current study was therefore tested using Cronchbar Reliability test with the help of SPSS, Version 22, which obtained a reliability coefficient of 0.77413 . Trustworthiness to qualitative data is what validity and reliability are to quantitative data. After being granted permission for the research, the researcher approached the Principals of schools that were sampled for the study for introduction and a request to collect data from their schools. After the formalization, dates were set when the school administration availed the students according to the sampling procedure, the students were briefed and their consent sought. After which, the questionnaires were administered. It took each student about 35 minutes to fill the questionnaire. The researcher then sought audience with the Deputy Principals and Class Teachers for the interviews. Data collection lasted a period of 30 days.

\section{Findings \& Discussion}

The study sought to examine the correlation between permissive parenting style and exam malpractice among students through Bivariate Pearson correlation. Using a two tailed correlation coefficient, the results were as shown in the Table 1.

Table 1: Correlation between permissive Parenting Style and exam malpractice among students

\begin{tabular}{|c|c|c|}
\hline Permissive Parenting Style & Statistics & Exam malpractice among students \\
\hline & Pearson Correlation & $.641^{\prime \prime}$ \\
\hline & Sig. (2-tailed) & .000 \\
\hline & $\mathrm{N}$ & 46 \\
\hline
\end{tabular}

The Pearson correlation result shown above implies a strong positive correlation between permissive parenting Style and exam malpractice among students, with $(r=0.64, P<0.05)$, hence a positive correlation. These findings can be explained by the fact that these children experience little or no external behavioral control especially from the parents. These findings support those of other scholars who had conducted similar studies on parenting styles. For instance, Garcia and Gracia (2009), found that adolescents who characterized their parents as indulgent/ permissive scored more positively on all the measures of psychological maladjustment than did those from authoritarian and neglectful families except for emotional instability. Similarly, Guastello and Marianne (2011), found a significant positive relationship between permissive parenting style and child behaviour problems.

Similarly, an interview session with the Teachers Counselors found that permissive parental encouraged indiscipline behavior among the students. For instance, one of the Teacher Counselors had to say:

Permissive parenting is characterized by hand off and laxity among the parents, and this could encourage the student to develop deviant behavior in school, because the student feels that his/her parent does not care about his/her character development [Teacher Counselor, 5].

This shows that permissive parenting could also encourage exam cheating as a form of deviant behavior in schools. These sentiments were also supported by the observations made by 
one of the deputy principals who said:

"Permissive parenting may encourage the students to indulge in indiscipline behaviour including exam malpractice because they believe that their parents would not blame them for their behaviour in schools" [Deputy Principal 8].

These sentiments are also echoed by Akinsola (2010), who also found that permissive parenting style correlated positively and significantly with liberal permissive, promiscuous and loose attitudes. Similarly, Igbo, \& Ihenjiene, (2014) in Nigeria who found that permissive parenting styles did not make any significant contribution to academic achievement of the student. On the other hand, there are studies whose findings are contrary to the findings of this study, for example, Kazemi et al (2012), found that the employment of permissive parenting style by mothers can lead to more adaptability. Olowodunaye et al (2011), found a negative relationship between permissive parenting style and exam malpractices.

\section{Conclusion and Recommendation}

According to the study findings it can be concluded that; there is a positive correlation between permissive parenting style and examination cheating tendencies. The study recommended that the Teachers' Service Commission (TSC) should train more teacher counselors in schools to cope with the large number of students who have varied parental backgrounds. Specifically, the teacher counselors ought to be equipped to be conscious of the influence of parenting on the behaviour of students since the study established that patenting styles have a correlation with examination cheating behaviours. The Principals and The Boards Of Management of schools should come up with policies that would aim at character mentorship so as to address the gaps from parenting in the home environment this is because the study established that permissive parenting style has a positive correlation with examination cheating tendencies among secondary school students.

\section{References}

Akinsola, E. F., (2011). Relationship between Parenting Style, Family Type, Personality Dispositions and Academic Achievement of Young People in Nigeria. Ife psychologia, 19.2.p246-276.

Albright, S., Winston, W., \& Zappe, C. (2010). Data analysis and decision making (4th ed.). Retrieved from http://books.google.com

Ali, A. S. M. (2011). The Use of Non-Verbal Communication in Classroom. A paper presented in the $1^{\text {st }}$ Ineternational Conference on Foreign Language Teaching and Applied Linguistic Tabuk University.

Antonio, M. , Maria Jose H (2014). Effects of academic dishonesty on dimensions of spiritual well being and satisfaction; a comparative study of secondary school and university students. Assessment and evaluation in Higher education 2014, 39(3): 349-363.

Baumrind,D.(1991).The influence of parenting style on adolescent competence and substance use. Journal Of Early Adolescence, 11(1),56-95.

Benedette, U., Corneliu, U., Ndifon, R. A. \& Obima, I. E. (2012). Correlates of Examination Malpractice and Academic Performance of Primary school Students in Cross River State. American Journal of Social Issues \& Humanities 2(6) 398-405

Changalwa , N., Ndurumo , M. , Barasa , L. \& Poipoi, W. (2012).The Relationship between Parenting Styles andAlcohol Abuse among College Students in Kenya. Greener Journal of Educational Research .Vol. 2 (2), pp. 013-020

Chinamasa, E. Mavuru, L. Maphosa C., \& Tarambawamwe (2011) Examination cheating, exploring strategies and contributing factors in Universities in Zimbabwe. Group Journal.Vol 1.No1.pp 1-23

Christopher, M., Eden, M., Melody, E., (2014) Examination Cheating Attitude \& Intensions Of Students In A Ghananian Polytechnic. Journal Of Teaching In Travel \& Tourism. Vol 16(1) pags 1-19.

Creswel , J. W \& Plano, V.L (2011). Designing And Conducting Mixed Methods Research ( ${ }^{\text {nd }}$ ed.) Thousand Oaks, CA: Sage.

Delameter, J. D. \& Myers, D.J. (2011). Social Psychology, $7^{\text {th }}$ edition, Belmont: Wadsworth Cengage Learning.

Desalegn, A. A., .\& Berhan, A .(2014). Cheating on Examinations and its predictors among undergraduate students at Hawassa University College of Medicine and Health Science, Hawassa, Ethiopia. .BMC Med $E D$, doi:10.1186/1472-6920-14-89 
DeVault, G. (2016). Establishing trustworthiness in qualitative reserch. Retrvied from:https:/www.thebalance.com/establishing-trustworthiness-in-qualitative research-2297042 on $17^{\text {th }}$ August, 2016

Fan, J. \& Wang, L., Y.(2016). Projected principal component analysis in factor models. Annalysis Statistics Journal. 44. No1.pp 219-254

Fayeke, O. D. (2014). Parenting Style and primary School Pupil's reading achievement. African Research Journal, Vol 5, No 9. Pages 280-293.

Fowler, F.J. \& Cosenza, C., (2008). Writing Effective Questions; Handbook of Survey Methodology. London Psychological Press.

Garcia, F., \&Gracia, E. (2009): Is always authoritative the optimum parenting style? Evidence from Spanish families. Spring: 44(173):101-31:

Gentina, E. ,Tang, T.L.P.,\& Gu, Q. (2015). Does Bad Company Corrupt Good Morals? Social Bonding and Academic Cheating Among French and Chinese Teens. Journal Of Business Ethics. 1-29 (1)

Henning A, Ram S, Malpas P, Shulruf B \& Hawken S. J.(2013). Academic Dishonesty and Ethical Reasoning; Pharmacy and Medical Students in New Zealand. Medical Teaching 2013, 35(6):1211-1217

Hingowei, Y. Perry, L. Rishi, S, Byron, R. \& Brandon (2016). What Contributes To College Students Cheating? A Study Of Individual Factors. Ethics \& behaviour Journal. Vol 27 (1) pgs 401-422.

Igbo, J. N. \& Ihenjiene, A., M. (2014). The Influence of Parenting Styles on Deviant Behaviors and Academic Achievement of Secondary School Students in Garoua, Northern Cameroon. International Journal of Educational Science and Research. 4(5).19-34.

Jackson, S. L. (2014). Research methods and statistics: A critical thinking approach(5th ed.). Boston: CengageLearning. Retrieved from https://books.google.com/

Kafwa, N.,Mwaka, M., \& Musamas, K. (2014) Evaluation Dilemma in Kenya Education System. International Journal Soc. Sci \& Education. Vol 4. Issue 2. ISSN 2223-4934 E

Kazemi A. Solokiansoheila, A. E., \& Marofi, M. (2012). The relationship between Mothers' Parenting Style and Social Adaptability of Adolescent Girls in Isfahan. Iranian Journal of Nursing and Midwifery. 17 (2) 101 106.

Lashgari, H. Karami, H. \& Golzari, F. (2014). Investingation Of Anxiety In Students With Learning Disabilities Based On Parenting Style. The Neuroscience Journal Of Shefaye Khatam. Vol 2.(1). 131-131

Latova and Latov (2008). Cheating in the educational process ( an experiment in crib -sheet studies. Russian education society. Vol 50 , No 7 , Pgs $17-43$

Leopard , J.M. (2017). Language and cheating in Higher Learning Education examinations- A Case Study of the Open university of Tanzania. European Journal Of Foreighn Language Teaching. Vol 2. Issue 2. ISSSN 2537-1754

Marek, Helen, Klein,\& Nancy (2013); Cross cultural evaluation of academic cheating in academia-a comparison of data from US and India. Journal of Teaching in International Business 18:81-99

Mason, M. (2010). Sample Size and Saturation in PHD studies Using Quantitative Interviews. Forum Qualitative Socialiforschung. Quantitative Social Research .Vol 11, No 3. Art 8,http://nbn-resolving.de/urn:de0114fgs 100387

Maxwell, J.,Molina-Azorin , J., F, Niglas, K. (2016). The Future of Mixed Methods: A five year Projection upto 2020. Mixed Methods International Research Association Wild Apricot.

Meng, C., Othman, J., J D’Silva, J. ,\& Omar, Z. , (2008). Ethical Decision Making in Academic Dishonesty with Application ofModified Theory of Planned Behavior: A Review. International Education Studies; Vol. 7, No. 3; Pgs 126-135

Morgan, D. (2007). Paradigms Lost and Paradigmns Regained: Methological Implications of Combining Qualitative and Quantitative Method. Journal of Mixed Methods Research; vol1, pp48

Mugenda, O. and Mugenda, A.,(2012). Research methods: Qualitative and quantitative Approaches. Acts press, Nairobi.

Mukras, M. (2013). Examination Cheating and Creadibility of University Degrees: Won't Continued Cheating Ultimately Undermine the Creadibility of University Degrees? Nairobi Press;

Mutwiri,J. (2010). Effects of High Stake Examinations: Challenges Associated with Implementation of Control Mechanisms: Association for Educational Assessment in Africa Conference (2010)

Mwaka, M, Kegode, G. and Wambua, B., K. (2010) Choosing the Right School: Redefining Performance in the contemporary Kenyan Educational System. Journal of African studies in Educational Mnagement and Leadership.

Mwamwenda, T. S (2013). Maintaining Academic Intergrity Among East African University students. Africa Education Review. Vol 9, issue 3 .pages 452-465.

Ndege, J. G. (2012). Approaches Used in Handling Cheating in Examinations, in Public National Examinations. Unpablished masters' thesis, University Of Nairobi.

Ogunlade, O. , \& Bello, O. (2013) : Cheating Among Students in the Digital Age; $7^{\text {th }}$ International Technolog , Educational And Development. Pg 61-68. 
Olowodunoye, S; \& Oyeboade A. (2011). Parenting Styles, Gender, Religiosity and Examination Malpractices. Academic Journal on Gender and Behavior 9 (2) 3941-4050.

Oso, Y. \& Onen, D. (2011). writing research proposal and report. Jomo Kenyatta Foundation

Ravasco , G. G. (2012). "Technology- Aided Cheating in Open Distance-e- Learning”. In The Asian Journal Of Distance Education University Of Phillipines Open University, Phillippines Vol 10. No2 .pp 71-77.

Russel , J. , Kirsten, K. \& Janice, L. (2011). Parental sedentary restriction, maternal parenting style and television viewing among 10-11 year olds. Pediatrics Journal. Issue 128 No 3. Pgs 572-578

Schiphorst, A. K. (2013). Students' Justification For Academic Cheating and Empirical Explanations of Such Behaviour. Social Cosmos., Vol 4. Issue 1, pp 57-63

Simkin, M.G. \& McLeod, A. (2010). Why do College Students Cheat?. Journal of Business Ethics, 94, 441-453.

Watson, G., \& James , S. (2010). Cheating In The Digital Age: Do students cheat more in online Courses?. Journal of Distance Learning, 13.1 (2010)pg.web.

Whitley, B. E., \& Kite , M. E. ( 2012). Principles of Research in Behavioral Science. Retrieved fromhttp://books.google.com 